\title{
Penggunaan Metode Pembelajaran Outdoor Learning untuk Meningkatkan Hasil Belajar Siswa pada Subkonsep Vertebrata
}

\author{
Gina Ganjar Maulana, Jusep Saputra \\ MA Ulul Albab, Pendidikan Matematika FKIP Universitas Pasundan \\ Jl. Tamansari No 6-8 Bandung \\ e-mail: ggm2425@gmail.com, jusepsaputrapmat@unpas.ac.id
}

\begin{abstract}
Abstrak
Tujuan dari penelitian ini adalah untuk mendapatkan informasi tentang metode pembelajaran Outdoor Learning untuk meningkatkan hasil belajar siswa, khususnya sub konsep vertebrata dalam proses pembelajaran. Metode penelitian kuasi eksperimental dengan rancangan kelompok kontrol kuasi eksperimental tanpa kuadrat (tidak ada rancangan kelompok kontrol yang setara) yang melibatkan setidaknya dua kelompok. Subjek adalah siswa SMA Pasundan 3 kelas Bandung X-1 dan X-2 dengan jumlah siswa pada masing-masing 30 orang. Data diperoleh dengan hasil pretes dan postes. Instrumen dalam penelitian ini adalah uji pilihan ganda pilihan sebanyak 20 pertanyaan. Berdasarkan hasil penilitian, metode pembelajaran Outdoor Learning dapat meningkatkan hasil belajar.
\end{abstract}

Kata kunci: Outdoor Learning, hasil beajar, vertebrata

\begin{abstract}
The purpose of this study was to obtain information about the Outdoor Learning teaching methods to improve Student Results, especially in sub concept of Vertebrates in the learning process. Quasi-experimental research methods with the quasi-experimental nonequivalent control group design (no equivalent control group design) involving at least two groups. Subjects were high school students Pasundan 3 Bandung class X-1 and X-2 by the number of students in each 30 people. Data obtained with pretest results and posttest. Instrument in this study were objective multiple-choice test of 20 questions. Based on the results research, method Outdoor Learning can improve learning outcomes.
\end{abstract}

Keywords: Outdoor learning, learning outcomes, vertebrate

\section{PENDAHULUAN}

Belajar merupakan suatu proses yang berkesinambungan dan tidak terlepas dari kondisi pelajar situasi sekitarnya. Hasil-hasil pengajaran dan pembelajaran berbagai bidang studi terbukti kurang memuaskan berbagai pihak hal tersebut disebabkan oleh tiga hal. Pertama, pengembangan kebutuhan dan aktifitas berbagai bidang kehidupan selalu meninggalkan proses/hasil kerja lembaga pendidikan atau melaju lebih dahulu dari pada proses pengajaran dan pembelajaran sehingga hasil-hasil pengajaran dan pembelajaran tidak cocok dengan kenyataan kehidupan yang diarungi oleh siswa. Kedua, pandangan-pandangan dan temuan-temuan kajian dari berbagai bidang tentang pembelajaran dan pengajaran membuat paradigma, falsafah, dan metodologi pembelajaran yang sekarang tidak memadai atau tidak cocok lagi. Ketiga, berbagai permasalahan dan kenyataan negative tentang hasil pembelajaran dan pengajaran menuutut diupayakannya pembaharuan paradigma, falsafah, dan metodologi pengajaran dan pembelajaran (Hamdan, 2008: 1).

Metode pembelajaran yang digunakan umumnya ceramah dan diskusi serta pemberian tugas. Oleh sebab itu, untuk menciptakan proses pembelajaran yang partisipatif aktif diperlukan adanya pendekatan dan metode pembelajaran yang sesuai. Dengan metode pembelajaran yang baik diharapkan muncul generasi penerus bangsa yang berkualitas dan mampu menyesuaikan diri untuk hidup bermasyarakat, berbangsa dan bernegara. The Director General of Teachers and Education Personnel (GTK) reported that based on the results of Teacher Competency Test (UKG) administered at the end of 2015, the average scores was 53.02. The competencies tested are professional competence and pedagogic competency. Based on the data, it is still necessary to improve the quality of teachers in Indonesia, Darta \& Saputra (2018: 2).

Jika tidak dilakukan perubahan dalam proses pembelajaran, maka sikap siswa tetap pasif, level berpikirnyapun hanya pada tahap remembering, hafalan dan jika diberi soal berpikir dan konseptual mereka tidak mampu 
menyelesaikannya. Akibatnya nilai yang dicapai rendah. Itulah konsekuensi yang harus ditanggung jika tidak dilakukan upaya perubahan dan perbaikan, peningkatan kualitas pembelajaran dan prestasi siswa tidak akan terwujud, belajar bukanlah kegiatan mengumpulkan data, tetapi membentuk makna melalui pengalaman dan proses belajar yang terjadi secara terus menerus secara mandiri atau kelompok. Kemandirian belajar peserta didik pun bisa dicapai jika dalam proses pembelajaran memberi kesempatan terbuka bagi mahasiswa untuk belajar secara mandiri, (Saputra, 2017: 117).

Ini berarti siswa harus dilatih untuk mempergunakan pengalaman dalam membentuk pengetahuan. Demikian pula siswa harus dibimbing agar mampu mandiri dalam belajar dan tidak menganggap guru sebagai sumber pengetahuan, tapi sebagai fasilitator dan moderator dalam proses pembelajaran. Perubahan sikap dan pandangan tersebut akan mendorong aktivitas mandiri dalam membentuk pengetahuan.

Berdasarkan observasi yang dilakukan pada tanggal 26 April 2012 oleh peneliti di SMA Pasundan 3 Bandung, bahwa terdapat salah satu permasalahan mengenai hasil belajar siswa pada subkonsep Vertebrata. Hal ini didukung oleh hasil wawancara dengan salah satu guru mata pelajaran Biologi di SMA Pasundan 3 Bandung, bahwa proses pembelajaran masih menggunakan metode ceramah, sehingga dari hasil belajar terhadap materi yang disampaikan kurang optimal karena siwa tidak mengalaminya secara langsung.

Selanjutnya belajar dengan metode Outdoor Learning menurut Suyadi, memiliki kekuatan antara lain, 1) Dengan pembelajaran yang variatif siswa akan segar berpikir karena suasana yang berganti, 2) Inkuiri lebih berproduksi, 3) Akslerasi lebih terpadu dan spontan, 4) Kemampuan eksplorasi lebih runtut, dan 4) Menumbuhkan penguatan konsep. Lebih lanjut, Suyadi menyebutkan bahwa manfaat pembelajaran Metode Outdoor Leearning antara lain: pikiran lebih jernih, pembelajaran akan terasa menyenangkan, pembelajaran lebih variatif, belajar lebih rekreatif, belajar lebih riil, anak lebih mengenal pada dunia nyata dan luas, tertanam image bahwa dunia sebagai kelas, wahana belajar akan lebih luas dan kerja otak lebih rileks sehingga siswa akan mampu mengembangkan dan membentuk pengetahuan secara benar dan hasil belajar yang meningkat.

Dengan demikian pembelajaran dengan menggunakan metode Outdoor Learning , diharapkan dapat terbantu untuk lebih kritis, dapat melihat kekurangan, dapat menumbuhkan rasa sosial yang tinggi, dan dapat meningkatkan hasil belajar pada siswa. Berdasarkan pernyataan di

atas maka penulis terdorong untuk meneliti dengan judul "Penggunaan Metode Pembelajaran Outdoor Learning untuk Meningkatkan Hasil Belajar Siswa pada Subkonsep Vertebrata".

Berdasarkan latar belakang yang sudah dikemukakan, dirumuskan masalah penelitian sebagai berikut: "Apakah Penggunaan Metode Pembelajaran Outdoor Learning Dapat Meningkatkan Hasil Belajar Siswa pada Subkonsep Vertebrata?"

Dalam proses belajar mengajar seorang guru harus mampu memilih model pembelajaran atau metode yang dapat menunjang proses belajar siswa aktif, kreatif dan inovatif. Dalam memilih satu metode pembelajaran, guru harus memahami tidak hanya karakteristik materi yang akan diajarkan tetapi juga harus melihat kondisi siswa yang belajar serta beberapa faktor lain yang berpengaruh terhadap proses belajar.

Metode Pembelajaran adalah seluruh perencanaan dan prosedur maupun langkahlangkah kegiatan pembelajaran termasuk pilihan cara penilaian yang akan dilaksanakan. Metode Pembelajaran dapat dianggap sebagai sesuatu prosedur atau proses yang teratur suatu jalan atau cara yang teratur untuk melakukan pembelajaran (Suyono dan Hariyanto, 2011: 19). Dekat dengan Metode Pembelajaran adalah Sintaks, sintaks adalah urutan langkah-langkah kegiatan pembelajaran sesuai dengan strategi dan metode yang dipilih. Istilah sintaks umum digunakan dalam ilmu bahasa, tetapi disini dimaknai sebagai suatu sistem atau penyusunan yang teratur berdasar urutan-urutan yang semestinya harus dilakukan (Suyono dan Hariyanto, 2011: 19).

Outdoor Learning tidak sekedar memindahkan pelajaran ke luar kelas, tetapi dilakukan dengan mengajak siswa menyatu dengan alam dan melakukan beberapa aktivitas yang mengarah pada terwujudnya perubahan perilaku siswa terhadap lingkungan melalui tahap-tahap penyadaran, pengertian, perhatian, tanggungjawab dan aksi atau tingkah laku. 
Aktivitas luar kelas dapat berupa permainan, cerita, olahraga, eksperimen, perlombaan, mengenal kasus-kasus lingkungan di sekitarnya dan diskusi (Husamah, 2011).

Beberapa konsep yang melandasi pendekatan outdoor learning adalah : (1) Pendidikan selama ini tidak menempatkan anak sebagai subjek; (2) Setiap anak berkebutuhan khusus dan unik. Mereka mempunyai kelebihan dan kekurangan, sehingga proses penyeragaman dan penyamarataan akan membunuh keunikan anak. Keunikan anak yang berkebutuhan khusus harus mendapat tempat dan dicarikan peluang agar anak dapat lebih berkembang; (3) Dunia anak adalah dunia bermain, tetapi pelajaran banyak disampaikan tidak lewat permainan; (4) Usia anak merupakan usia yang paling kreatif dalam hidup manusia, namun dunia pendidikan kurang memberikan kesempatan bagi pengembangan kreativitas.

Konsep Outdoor Learning ini sejalan dengan pendapat Dryden yang menyarankan melibatkan orangtua, kakek/nenek, dan masyarakat dalam proses belajar. Peran serta masyarakat dan orang-orang di sekitar sekolah dalam proses pembelajaran di sekolah dapat mengatasi keterbatasan guru dalam memperoleh informasi terkini. Selain itu, dengan memanfaatkan sumber belajar di luar kelas, siswa dapat memperoleh suasana baru yang dapat membuat mereka lebih fun, sehingga pembelajaran akan berlangsung dengan dinamis.

Tahapan proses pembelajaran dengan menggunakan metode Outdoor Learning untuk meningkatkan hasil belajar siswa dapat ditempuh dengan (Hamdan, 2008, hlm. 20) Guru menentukan lokasi di luar kelas, Guru membagi siswa menjadi beberapa kelompok, Guru membuat panduan belajar siswa di luar kelas, Guru mengajak siswa ke luar kelas untuk melaksanakan proses pembelajaran, Guru mengajak siswa untuk berkumpul sesuai kelompoknya, Memberi salam dan mengabsen siswa, Memberi motivasi kepada siswa tentang pentingnya lingkungan sebagai sumber belajar, Guru memberikan panduan belajar kepada masing-masing kelompok disertai dengan penjelasan, Masing-masing kelompok berpencar pada lokasi untuk melakukan pengamatan sesuai dengan yang di tugaskan guru, Guru membimbing siswa selama pengamatan, Setelah siswa selesai melakukan pengamatan selanjutnya siswa diajak berkumpul kembali untuk mendiskusikan hasil pengamatan, Guru memandu siswa dalam melakukan diskusi dan diberi kesempatan memberi tanggapan, Guru memberikan kesempatan kepada siswa untuk mengungkapkan hambatan/kesulitan yang dialami dalam proses pembelajaran

\section{PEMBAHASAN}

Berdasarkan hasil analisis data postest dengan menggunakan uji $\mathrm{t}$ didapatkan hasil bahwa $t_{\text {hitung }} 19,26>t_{\text {tabel }} 2,045$. Hasil tersebut menunjukkan bahwa terdapat perbedaan yang signifikan antara hasil belajar siswa pada kelas eksperimen dan kelas kontrol. Sedangkan untuk mengukur perbedaan peningakan kedua kelas, maka dihitung N-Gain nya.

Tabel 1. Peningkatan kedua kelas

\begin{tabular}{ccccccc}
\hline \multicolumn{4}{c}{ Kelas Kontrol } & \multicolumn{3}{c}{ Kelas Eksperiman } \\
Nilai & Pre & Post & $N-$ & Pre & Post & $N-$ \\
& test & test & Gain & test & test & Gain \\
\hline $\bar{x}$ & 32,7 & 42,7 & 0.15 & 47,3 & 79,8 & 0.62 \\
\hline
\end{tabular}

Jika dilihat pada Tabel 1 terdapat peningkatan pada kedua kelas tersebut, walaupun demikian bila dibandingkan dengan kelas kontrol yang menggunakan metode konvensional, peningkatan rata-rata pada kelas eksperimen yang menggunakan metode Outdoor learning jauh lebih besar.

Berdasarkan uraian diatas dapat disimpulkan bahwa karena adanya perbedaan perlakuan pada kelas kontrol dan eksperimen maka akan terjadi perbedaan pada pencapaian hasil belajar pada kedua kelas tersebut.

Sehingga penggunaan pembelajaran dengan menggunakan metode Outdoor Learning dapat meningkatkan hasil belajar siswa. Hal ini dapat terjadi karena pada pembelajaran dengan menggunakan metode Outdoor Learning siswa dibuat lebih aktif, dan bisa berhubungan langsung dengan lingkungan sekitar dan juga belajar dengan menggunakan lingkungan memungkinkan siswa menemukan hubungan yang sangat bermakna antara ide-ide abstrak dan penerapan praktis di dalam konteks dunia nyata, konsep dipahami melalui proses penemuan, pemberdayaan dan hubungan (Hamzah dan Nurdin, 2011: 145). Berbeda halnya dengan metode konvensional dimana yang lebih berperan aktif adalah guru, sedangakan siswa hanya menjadi objek yang diberikan sejumlah ilmu pengetahuan. Terkadang situasi belajar seperti ini membuat siswa kurang tertarik dan 
merasa jenuh dengan kegitan pembelajaran yang berlangsung.

Dilihat dari selisih rata-rata nilai postest kedua kelas dengan perlakuan yang berbeda tersebut, diketahui bahwa metode pembelajaran Outdoor Learning dapat meningkatkan hasil belajar siswa. Jadi, dengan demikian metode pembelajaran Outdoor Learning dapat digunakan sebagai salah satu bentuk alternatif dalam kegiatan pembelajaran.

\section{KESIMPULAN}

Berdasarkan hasil penelitian yang telah dilaksanakan di SMA Pasundan 3 Bandung mengenai penggunaan metode pembelajaran Outdoor Learning dalam meningkatkan hasil belajar siswa pada subkonsep vertebrata, maka dapat dikemukakan kesimpulan bahwa pembelajaran dengan menggunakan metode pembelajaran Outdoor Learning dapat meningkatkan hasil belajar siswa.

Hal ini terlihat dari nilai rata-rata pretest kelas eksperimen yang menggunakan metode pembelajaran Outdoor Learning, yaitu 47,33 dan nilai rata-rata posttest 79,83 yang mengalami peningkatan secara signifikan jika dibandingkan dengan kelas kontrol yang menggunakan metode konvensional.

Dari hasil perhitungan uji hipotesis dapat kita peroleh bahwa untuk data pretest pada kelas kontrol dan eksperimen $t_{\text {hitung }} \geq \mathbf{t}_{(0,01)(30)}$, yaitu $7,37 \geq 2,76$ yang artinya $\mathrm{H}_{0}=$ ditolak dan $\mathrm{H}_{1}=$ diterima. Untuk data posttest kelas kontrol dan eksperimen $t_{\text {hitung }} \geq \mathrm{t}_{(0,01)(30)}$, yaitu $19,86 \geq$ 2,76 yang artinya $\mathrm{H}_{0}=$ ditolak dan $\mathrm{H}_{1}=$ diterima. Maka dapat disimpulkan bahwa awal hasil belajar dan akhir hasil belajar menunjukan perbedaan yang signifikan atau terjadi peningkatan dengan penggunaan metode pembelajaran Outdoor Learning .

\section{DAFTAR PUSTAKA}

Darta \& Saputra, J. (2018). Indicators that Influence Prospective Mathematics Teachers Representational and Reasoning Abilities. Journal of Physics: Conference Series 948 (1), $012053 . \quad$ DOI : $10.1088 / 1742-$ 6596/948/1/012053.

Hamdan, A. (2008). Efektifitas Pembelajaran Biologi Melalui metode Outdoor Study dalam Upaya Meningkatkan Minat Belajar Siswa .Jakarta: Bionature.

Husamah. (2011). Optimalisasi Penerapan Pendidikan Karakter di Sekolah Menengah Berbasis Keterampilan Proses: Sebuah Perspektif Guru IPA Biologi. Jurnal Penelitian dan Pemikiran Pendidikan/. 1 (1), 69-81.

Saputra, J. (2017b). Penggunaan Model Problem Based Learning Berbantuan ELearning Terhadap Kemandirian Belajar Mahasiswa pada Dimensi Tiga. KALAMATIKA Jurnal Pendidikan Matematika, 2 (2), 117 130.

DOI: http://dx.doi.org/10.22236/KAL AMATIKA.vol2no2.2017pp117-130

Suyono dan Hariyanto, (2011). Belajar dan Pembelajaran. Bandung: PT Remaja Rosdakarya Offset.

Hamzah \& Nurdin (2011). Belajar dengan Pendekatan PAILKEM. Jakarta: PT Bumi Aksara 